Journal of Islamic Medicine

Volume 1(1) (2017), Pages 9-21

\title{
Gagal Jantung Kiri dan Hipertensi Pulmonal
}

\author{
Djanggan Sargowo ${ }^{1}$ \\ ${ }^{1}$ Departemen Jantung dan Pembuluh Darah, RSSA Malang \\ Email : djanggan@yahoo.com
}

\begin{abstract}
In patients with left heart failure, pulmonary hypertension and right ventricular dysfunction is a common condition and has important implications in the development of disease, disability and death, so it required special attention. Pulmonary hypertension is the most common form with approximately 65$80 \%$ of cases. Although today is already highly developed understanding of the pathophysiology and clinical assessment, as well as setting the hemodynamic definition and classification of pulmonary hypertension in left heart failure, but the interrelation hemodynamics in pulmonary hypertension combination of pre- and post-capillary is still very complex, and there is no evidence-based recommendations the handling of pulmonary hypertension is left heart failure. Here, we will discuss the prevalence and significance of pulmonary hypertension and cardiac dysfunction Right in patients with both heart failure with ejection fraction decreased, as well as heart failure with ejection fraction, as well as provides an overview of the pathophysiology of the complex due to the interaction of cardiopulmonary left heart failure, which can supports the evolution of the phenotype of the left ventricle into the right ventricle phenotype through the travel history of heart failure. Next, we will discuss fenoitp pulmonary hypertension by combining the clinical context, the assessment of non-invasive and invasive hemodynamic variables in a structured diagnostic assessment.
\end{abstract}

Keywords: Pulmonary hypertension, heart failure, Pre-capillary, Post-capillary

\begin{abstract}
ABSTRAK
Pada pasien gagal jantung kiri, terjadinya hipertensi pulmonal dan disfungsi ventrikel kanan adalah kondisi yang sering ditemukan dan memiliki implikasi yang penting pada perkembangan penyakit, kecacatan dan kematian, sehingga sangat diperlukan perhatian khusus. Hipertensi pulmonal merupakan bentuk yang tersering dengan kurang lebih $65-80 \%$ kasus. Walaupun saat ini sudah sangat berkembang pengertian mengenai patofisiologi dan penilaian klinis, serta pengaturan pada definisi hemodinamik dan klasifikasi hipertensi pulmonal pada gagal jantung kiri, namun interelasi hemodinamik pada kombinasi hipertensi pulmonal pre- dan post-kapiler masih sangat kompleks, dan tidak ada rekomendasi berbasis bukti pada penanganan hipertensi pulmonal pada gagal jantung kiri. Disini, akan dibahas mengenai prevalensi dan signifikansi hipertensi pulmonal dan disfungsi jantung kanan pada pasien dengan baik gagal jantung dengan fraksi ejeksi menurun, maupun gagal jantung dengan fraksi ejeksi baik, serta memberikan pandangan mengenai patofisiologi yang kompleks akibat interaksi kardiopulmoner pada gagal jantung kiri, dimana dapat mendukung evolusi dari fenotip ventrikel kiri menjadi fenotip ventrikel kanan melalui riwayat perjalanan gagal jantung. Selanjutnya, akan dibahas mengenai fenoitp hipertensi pulmonal dengan menggabungkan konteks klinis, penilaian non-invasif, dan variabel hemodinamik invasif pada suatu penilaian diagnostik yang terstruktur.
\end{abstract}

Kata Kunci : Hipertensi Pulmonal, Gagal jantung, Pre-kapiler, Post-kapiler.

\section{PENDAHULUAN}

Hipertensi pulmonal (HP) merupakan suatu kondisi yang cukup sering, yang terjadi sebagai konsekuensi penyakit vaskuler paru, penyakit paru kronis atau penyakit jantung kiri, emboli paru, atau etiologi lainnya. Diantara semua jenis HP, HP yang berhubungan dengan gagal jantung kiri (left heart failure / LHF) merupakan jenis yang tersering. Penyakit jantung kiri (left heart disease/LHD) 
mewakili sekitar $65-80 \%$ dari seluruh kasus HP. Padahal terapi saat ini hanya tersedia untuk hipertensi arteri pulmonal (pulmonary arterial hypertension/PAH), dan terapi ini masih belum dievaluasi secara adekuat atau tidak diindikasikan dan dapat memberikan dampak buruk bagi pasien dengan HP yang berhubungan dengan penyakit jantung kiri (pulmonary hypertension with left heart disease/PH-LHD). Oleh karena itu, dibutuhkan suatu kriteria diagnosis pasti dan klasifikasi HP sebelum keputusan terapi dibuat. Meskipun demikian, pada praktek klinis, ada suatu inkonsitensi yang signifikan, dimana perlu diperhatikan, yaitu pada pasien dengan HP dan LHD yang tersembunyi yang seringkali disalah kategorikan sebagai PAH dan diterapi dengan obat-obatan yang spesifik untuk PAH, atau pada pasien HP dengan asal yang tidak jelas yang memperoleh terapi tanpa klasifikasi yang jelas. Sebaliknya, gagal jantung yang seringkali berhubungan dengan HP dan disfungsi ventrikel kanan, dimana memiliki dampak yang penting pada progresivitas penyakit, kecacatan dan kematian, seringkali diabaikan pada ruang lingkup al jantung. Namun, interelasi hemodinamik ketika suatu komponen pre-kapiler ditemukan pada kondisi HP akibat post-kapiler bersifat kompleks, dan efikasi dan keamanan pemberian terapi khusus pada HP masih belum dapat dibuktikan [1,3].

\section{DEFINISI HEMODINAMIK DAN KLASIFIKASI HIPERTENSI PULMONAL YANG BERHUBUNGAN DENGAN PENYAKIT JANTUNG KIRI}

Tanpa memperhatikan asalnya, HP didefinisikan sebagai tekanan arteri pulmonal (pulmonary artery pressure / PAP) rata-rata $\geq 25 \mathrm{mmHg}$. Berdasarkan tekanan pengisian ventrikel kiri [ditentukan baik sebagai LV end-diastolic pressure / LVEDP), left atrial pressure (LAP), atau pulmonary arterial wedge pressure (PAWP)], definisi hemodinamik secara lebih jauh dibedakan menjadi pre- ( $\leq 5$ $\mathrm{mmHg}$ ) dan post-kapiler (>15 mmHg). Pada HP post-kapiler, peningkatan PAWP menyebabkan peningkatan proporsional pada PAP rata-rata, untuk mempertahankan transpulmonary pressure gradient $(\mathrm{TPG}=\mathrm{mPAP}-\mathrm{PAWP})$ yang normal $<12 \mathrm{mmHg}$, dan pulmonary vascular resistence $(\mathrm{PVR})$ yang rendah < 3 Wood unit (WU) atau < 240 dynes s cm [5]. Meskipun demikian, peningkatan kronis tekanan pengisian ventrikel kiri yang berhubungan dengan aktivasi neurohormonal dan mediator lainnya sama seperti efek neurogenik dapat menyebabkan vasokonstriksi berlebihan dengan/tanpa remodeling vaskuler yang menyebabkan peningkatan yang tidak proporsional pada PAP, sehingga berakhir pada peningkatan TPG dan PVR, yang dikenal dengan istilah HP yang reaktif / out-ofproportion / mixed[2].Sementara TPG dipengaruhi oleh beban volume dan fungsi jantung, dan tidak dapat memprediksi outcome pada PH-LHD [3], diastolic pressure gradient (DPG) - didefinisikan sebagai perbedaan antara PAP dan PAWP pada saat diastolik - diperkirakan lebih tidak tergantung pada volume sekuncup dan kondisi pengisian, dan menunjukkan korelasi dengan remodeling vaskuler paru pada PH-LHD [4]. Temuan inilah yang merujuk pada terminologi dan klasifikasi terbaru HP post-kapiler yaitu isolated post-capillary PH (Ipc-PH), jika DPG $<7 \mathrm{mmHg}$ dan/atau PVR $\leq \mathbf{S} \mathrm{WU}$, atau combined post- and pre-capillary PH (Cpc-PH), jika DPG $\geq 7 \mathrm{mmHg}$ dan/atau PVR $>3 \mathrm{WU}[1,3]$

\section{PREVALENSI DAN SIGNIFIKANSI HIPERTENSI PULMONAL PADA GAGAL JANTUNG KIRI}

Keberadaan dan luas HP dan disfungsi ventrikel kanan - dimana keduanya seringkali ditemukan pada gagal jantung kiri - berhubungan dengan progresivitas penyakit, penurunan toleransi aktivitas, dan suatu outcome yang kurang baik. Data mengenai prevalensi HP pada pasien gagal jantung masih sangat bervariasi dan sangat bergantung pada hasil pengukuran PAP, definisi HP dan populasi yang dinilai. Walaupun baik $H F$ with reduced ejection fraction (HF-rEF) maupun $H F$ with preserved ejection fraction (HF-pEF) sama-sama menunjukkan gejala klinis gagal jantung, namun masing-masing memiliki muatan yang berbeda dalam hal patofisiologi, karakteristik klinis, hemodinamik, interaksi kardiopulmoner, dan respon terapi, sehingga perlu dilihat dalam sudut 
pandang yang berbeda. Pada HF-rEF, prevalensi HP yang dinilai dengan RHC dilaporkan terjadi antara 40-75\%. Pada pasien HF-pEF, studi terbaru menggunakan ekokardiografi maupun RHC mengindikasikan prevalensi HP antara 36-83\% [1,3].

Suatu studi berbasis komunitas pada pasien gagal jantung menunjukkan bahwa pulmonary artery systolic pressure (PASP) yang dinilai dengan ekokardiografi secara kuat memprediksi angka kematian akibat penyakit kardiovaskuler dan seluruh penyebab lain secara independen dibandingkan prediktor outcome lainnya yang pernah ada. Sementara banyak studi secara konsisten menunjukkan adanya korelasi terbalik antara HP dan angka harapan hidup, suatu kombinasi peningkatan PAP dan penurunan fungsi sistolik ventrikel kanan menunjukkan suatu outcome yang kurang baik pada pasien HF-rEF. Pada HF-pEF, banyak studi menunjukkan bahwa keberadaan HP berhubungan kuat dengan terjadinya kematian. Lebih lagi, pasien HF-pEF seringkali menunjukkan suatu disfungsi ventrikel kanan, yang berhubungan dengan peningkatan peningkatan PAP, yang terjadi pada stadium lanjut, dan merupakan suatu prediktor kematian yang kuat [1,4,7].

Parameter hemodinamik yang berhubungan dengan rendahnya angka harapan hidup meliputi peningkatan PAWP, PAP rata-rata, dan PVR, serta penurunan komplians/kapasitansi arteri pulmonal $[3,6]$. Studi terbaru mengenai nilai prognostik DPG pada PH-LHD masih menunjukkan hasil yang kurang memuaskan. Data terbaru mengindikasikan bahwa - tergantung pada pertimbangan DPG dan/atau PVR - prevalensi Cpc-PH pada pasien dengan gagal jantung adalah 12-38\%. Secara kolektif, data-data diatas menunjukkan bahwa HP dan disfungsi jantung kanan sering ditemukan dan berhubungan dengan outcome yang kurang bagus pada pasien dengan gagal jantung kiri $[4,6]$.

\section{PATOBIOLOGI HUBUNGANHIPERTENSI PULMONAL DENGAN PENYAKIT JANTUNG KIRI}

Patobiologi HP pada gagal jantung kiri sangatlah kompleks. HP utamanya terjadi akibat transmisi balik dari tekanan pengisian ventrikel kiri yang tinggi secara pasif, yang terjadi akibat disfungsi sistolik maupun diastolik ventrikel kiri (Gambar 1) [5]. Selanjutnya, regurgitasi mitral (MR) fungsional akan menyebabkan peningkatan LAP dan PAP, yang seringkali memberat saat aktivitas. Sebagai tambahan terhadap remodeling dan disfungsi ventrikel kiri, suatu peningkatan ukuran atrium kanan (yang secara relatif independen terhadap pengisian dan bertindak sebagai marker morbiditas dan mortalitas pada gagal jantung), fibrosis interstitial menyebabkan kekakuan atrium kiri, dan penurunan komplians atrium kiri, juga gangguan kontraktilitas atrium kiri, menyebabkan perubahan patogenik pada sirkuit pulmonal dan jantung kanan (Gambar 2). Perubahan pada sifat sistolik dan diastolik atrium kiri mempengaruhi pengisian jantung dan curah jantung, dan transmisi balik tekanan pengisian jantung kiri menyebabkan peningkatan tekanan paru, utamanya saat aktivitas. Secara konsisten, disfungsi atrium kiri berhubungan dengan timbulnya gejala pada pasien HF-pEF. Sebagai tambahan, disfungsi atrium kiri dapat pula menentukan respon terapi terhadap terapi HP khusus pada pasien dengan LHD, dimana penurunan PVR dan peningkatan aliran darah paru dapat menyebabkan peningkatan PAWP dan edema paru pada pasien dengan penurunan komplians atrium kiri [1]. 


\section{PULMONARY CIRCULATION}

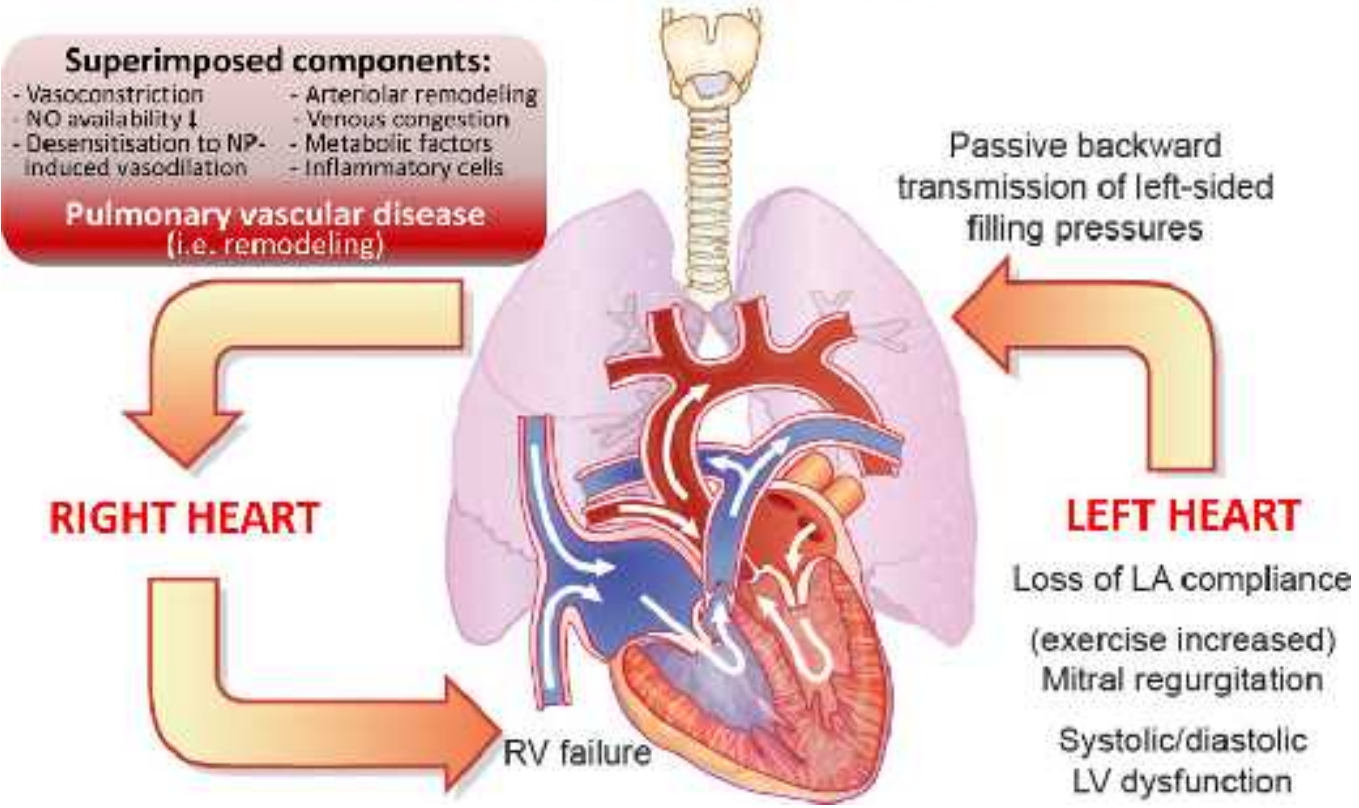

Gambar 1. Interaksi kardiopulmoner dan patobiologi hipertensi pulmonal pada gagal jantung kiri [1]

Pada sirkulasi pulmonal, peningkatan mendadak LAP dapat menyebabkan "alveolar-capillary stress failure", suatu barotrauma reversibel yang mengubah permeabilitas endotel sehingga menyebabkan kebocoran eritrosit, protein dan cairan menuju lumen alveolar, dan mengakibatkan edema interstitial dan alveolar. Peningkatan bertahap dari tekanan pengisian ventrikel kiri dan tekanan vena pulmonalis dapat diikuti oleh komponen dari sirkuit paru, yang mencakup penurunan availabilitas NO, peningkatan ekspresi endotelin-1, desensitisasi terhadap peptida natriuresis yang menginduksi vasodilatasi, infiltrasi sel inflamasi, dan faktor neurogenik atau metabolik [5]. Selanjutnya, hipoksia menyebabkan vasokonstriksi dan respon pertumbuhan pada sirkuit paru, dan takiaritmia, khususnya fibrilasi atrium, dan dapat merangsang terjadinya hipertensi pulmonal pada pasien dengan gagal jantung kiri. Komponen tambahan ini dapat mencetuskan vasokonstriksi arteri pulmonal, dan -seiring berjalannya waktu- remodeling struktur arteri dengan resistensi pulmonal yang kecil, mengindikasikan komponen pre-kapiler dari suatu HP dimana PAP kemudian meningkat pada peningkatan PAWP yang berlebihan (Gambar 1).Remodeling arteri pulmonal yang serupa dengan PAH ditemukan pada PH-LHD yang parah, khususnya pada pasien dengan Cpc-PH (DPG $\geq 7 \mathrm{mmHg}$ ). Perubahan histopatologi meliputi penebalan membran alveolar-kapiler, hipertrofi media, fibrosis intima dan adventitia, dan oklusi lumen pada arteriole pulmonal kecil, sedangkan lesi plexiformis yang sangat patognomonis pada PAH tidak selalu ditemukan [4], Berkebalikan dengan sirkulasi sistemik, dimana komplians vaskuler utamanya ditentukan oleh aorta, komplians arteri pada paru didistribusikan disepanjang jaringan vaskuler paru, sehingga resistensi (R) dan komplians (compliance/C) secara predominan ditentukan oleh pembuluh darah dengan resistensi kecil. Oleh karena itu, remodeling arteriole pulmonal utamanya berkontribusi pada peningkatan PVR dan penurunan komplians arteri pulmonal pada Cpc-PH [1]. 
A

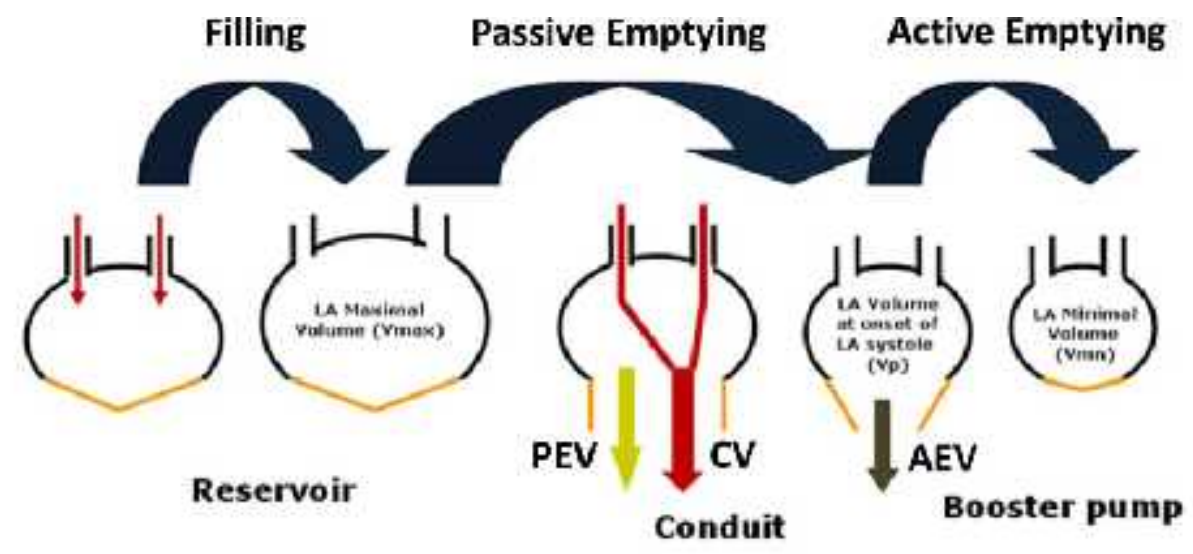

B

normal

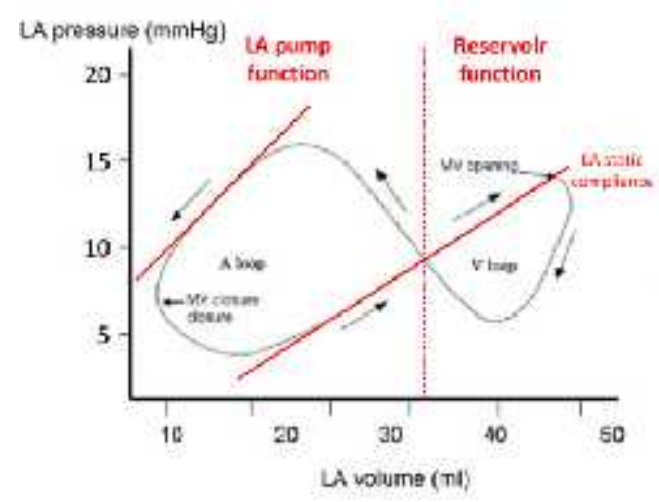

LA Dysfunction

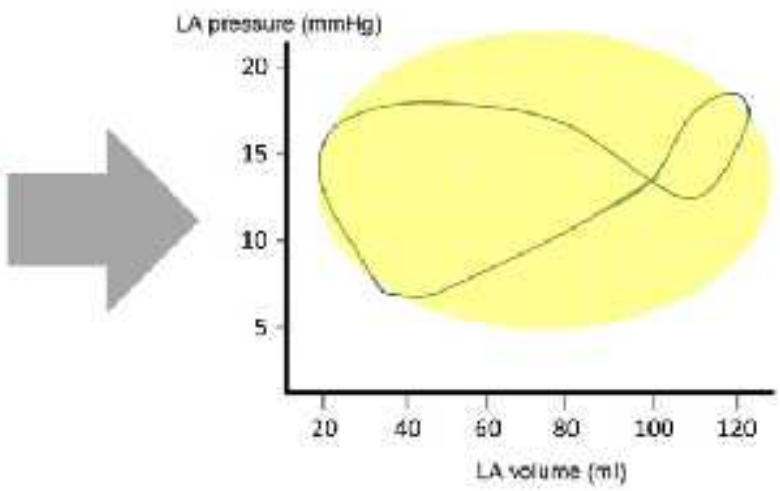

Gambar 2. Remodeling dan disfungsi atrium kiri pada gagal jantung. (A) Fase fungsi atrium kiri. PEV, passive emptying volume $=\mathrm{V}_{\max }-\mathrm{V}_{\mathrm{p}} ; \mathrm{CV}$, conduit volume $=\mathrm{LV}$ stroke volume $-\left(\mathrm{V}_{\max }-\mathrm{V}_{\min }\right)$; AEV, active emptying volume $=\mathrm{V}_{\mathrm{p}}-\mathrm{V}_{\min }$. (B) Tekanan atrium kiri - volume loops pada fungsi atrium kiri yang normal (kiri) dan disfungsi atrium kiri (kanan) [1]

Pada pasien PH-LHD terdapat hubungan yang terbalik antara $\mathrm{R}$ dan $\mathrm{C}$ pada sirkulasi paru [7]. Produk $\mathrm{R}$ dan $\mathrm{C}$ ( $R C$ time) menunjukkan penurunan pada PAP setelah katub pulmonal menutup. Ditemukan bahwa pada gagal jantung kiri dengan peningkatan PAWP, $R C$ time dibawah pengaruh peningkatan PAWP sedikit menurun dibandingkan pada PAH (Gambar 3). Hal ini diduga akibat remodeling vena pulmonal yang abnormal, peningkatan tonus vaskuler paru pada gagal jantung kiri, atau oleh karena peningkatan PAWP. Gradien tekanan antara PAP diastolik dan PAWP (DPG) tidak bergantung pada beban volume dan volume sekuncup dibandingkan TPG, dan adanya peningkatan DPG merupakan suatu indikator yang lebih baik dalam mendeteksi komponen pre-kapiler dari HP [6,7]. Implikasi lain dari RC yang konstan sangat tergantung dari hubungan terbalik antara komplians dengan resistensi. Komplians arteri pulmonalis merupakan marker yang lebih sensitif pada tahapan awal penyakit dibandingkan dengan PVR [1]. 


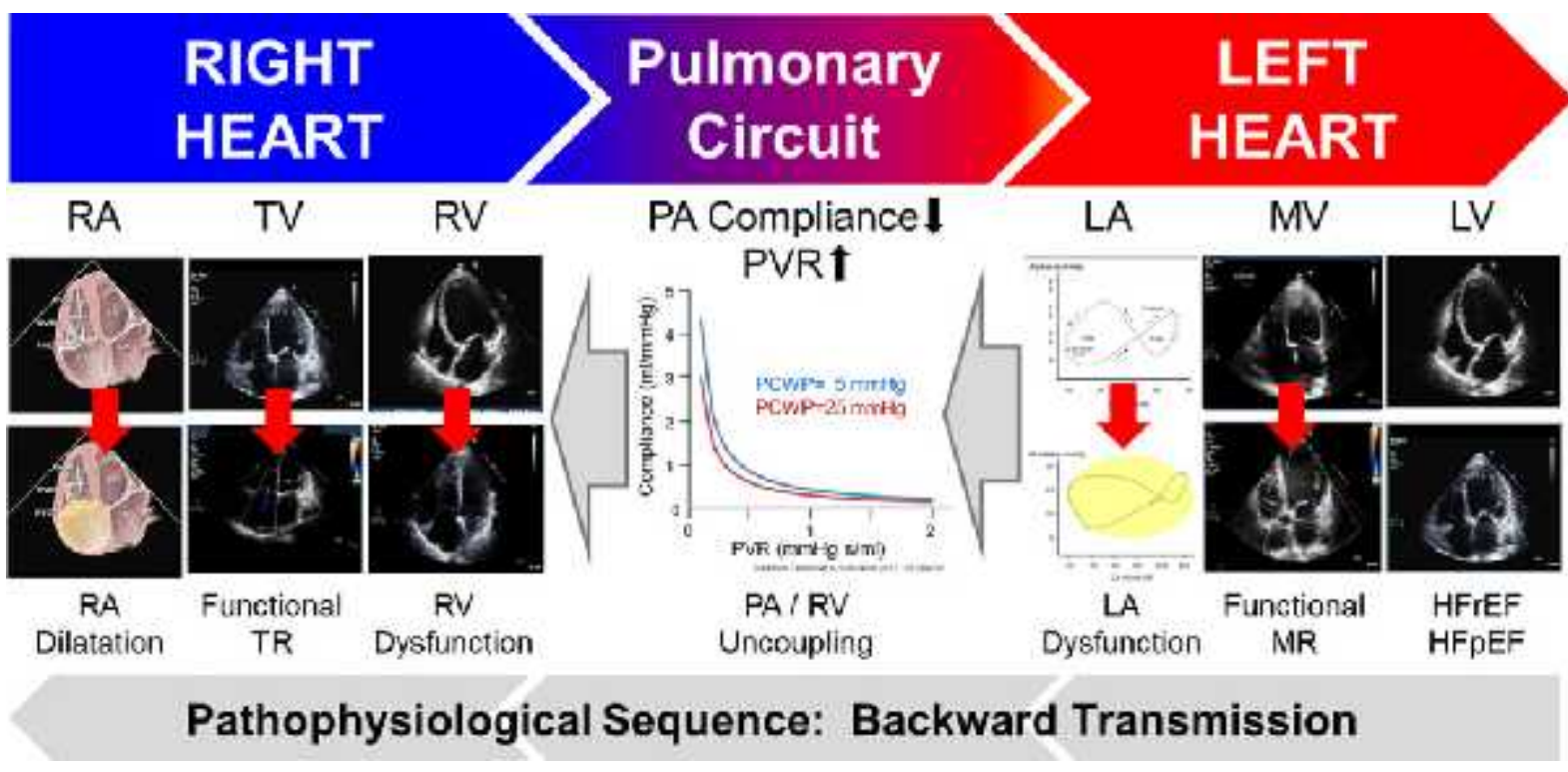

Gambar 3. Urut-urutan faktor patofisiologi yang berkontribusi pada hipertensi pulmonal pada LVHF. Transmisi balik dari kiri-ke-kanan pada level ventrikel, katub AV, dan atrium [1]

Peningkatan tekanan pulmonal dan PVR menunjukkan suatu peningkatan afterload ventrikel kanan baik resistif maupun pulsatile, yang menyebabkan remodeling maladaptif dan dilatasi ruang jantung kanan, regurgitasi fungsional trikuspid, dan pada akhirnya disfungsi ventrikel kanan, yang berakibat curah jantung yang rendah (suatu determinan outcome pada PH-LHD). Perubahan patologis yang terjadi meliputi hipertrofi, fibrosis dan dilatasi ventrikel kanan, perubahan bentuk ventrikel kana dari bulan sabit menjadi sferis, yang berhubungan dengan regurgitasi trikuspid fungsional dan peningkatan RAP. Signifikansi prognostik suatu peningkatan PAP pada gagal jantung meningkat seiring dengan derajat disfungsi ventrikel kanan, tanpa menghiraukan LVEF. Namun, hubungan antara keparahan HP dan disfungsi ventrikel kanan tidaklah linier, dimana pada beberapa pasien dengan HP berat dapat menunjukkan fungsi ventrikel kanan yang normal $[1,5,7]$

\section{FENOTIP VENTRIKEL KIRI VS. VENTRIKEL KANAN}

Ada 2 faktor yang mempengaruhi heterogenesitas HP pada LVHF, yaitu : (1) Kerentanan terhadap penyakit vaskuler paru (oleh karena faktor genetik dan/atau stresor lingkungan dan/atau komorbiditas), dan (2) faktor "waktu". Pada pasien gagal jantung yang rentan terhadap vaskulopati pulmonal, maka suatu evolusi potensial dari penyakit ventrikel kiri menjadi dilatasi dan gangguan fungsi ventrikel kanan sebagai akibat HP dapat diamati. Selama evolusi ini, jantung berubah secara progresif mulai dari suatu gambaran ventrikel kiri yang abnormal dengan gambaran ventrikel kanan yang normal (fenotip ventrikel kiri), sampai gambaran dilatasi dan disfungsi ventrikel kanan yang bahkan melampaui abnormalitas ventrikel kiri (fenotip ventrikel kanan) (Gambar 4). Disfungsi ventrikel kanan pada pasien HF-pEF berhubungan dengan stadium penyakit yang lebih parah. Mortalitas meningkat ketika fenotip ventrikel kanan terjadi [8,9]. 


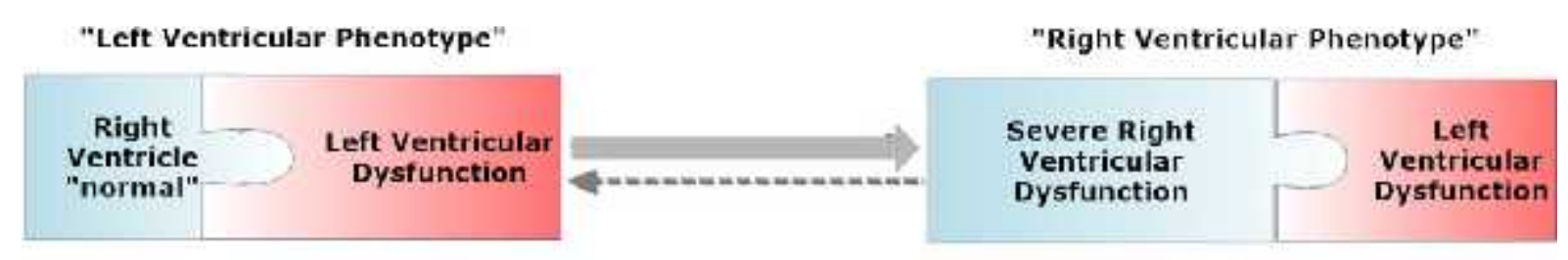

Spectrum of Right Ventricular Dysfunction and Presentation
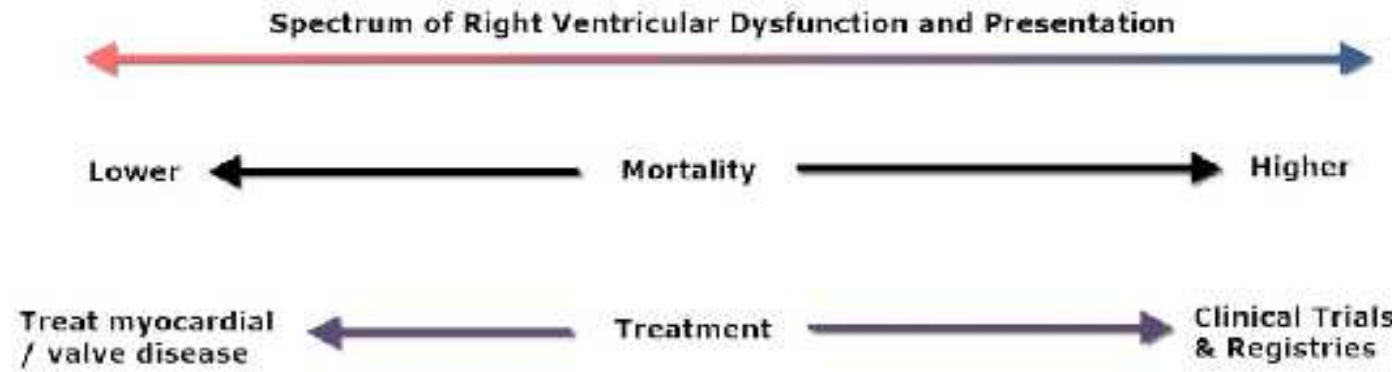

I valve disease

\& Registries

Post or Pre-capillary Pulmonary Hypertension

Resting Haemodynamics

Post or Pre-capillary

Pulmonary Hypertension

Gambar 4. Fenotip ventrikel kiri vs. fenotip ventrikel kanan pada hipertensi pulmonal yang berhubungan dengan penyakit jantung kiri. Tampak spektrum presentasi dari disfungsi ventrikel kanan, dampak pada mortalitas, implikasi terapeutik, dan hemodinamik paru dalam kondisi istirahat [1]

\section{DILEMA PENGUKURAN PAWP UNTUK MEMBEDAKAN HIPERTENSI PULMONAL PRE- DAN POST- KAPILER}

Pengukuran PAWP cenderung menyebabkan kesalahan signifikan sehingga berdampak langsung padaa klasifikasi HP dan keputusan terapi. Kelemahannya meliputi nilai ambang PAWP yang membedakan HP pre- dan post- kapiler, kesulitan teknis dalam mendapatkan perekaman pressure tracing yang benar, kurangnya standarisasi kalibrasi yang benar (zero level), dan metode pembacaan PAWP dalam hubungannya dengan siklus respirasi $[1,7]$.

Walaupun banyak dokter di seluruh dunia menggunakan patokan yang sama yakni $15 \mathrm{mmHg}$ sebagai dasar untuk membedakan HP pre- dan post- kapiler [2], beberapa ahli mengatakan bahwa penggunaan metode yang berbeda dapat menghasilkan variasi perbedaan antar 4-6 mmHg [9].Perbedaan ini disebabkan karena adanya variasi respirofasik pada tekanan intratorakal, dimana menunjukkan nilai yang lebih rendah saat inspirasi dan nilai yang lebih tinggi saat ekspirasi (Gambar 5A). Beberapa sumber kesalahan tambahan termasuk ketidakpastian mengenai nilai ambang dan dampak beban volume (Gambar 5B). Studi yang saling berlawanan telah dipublikasi terkait metode pengukuran PAWP dan potensi kesalahan klasifikasi antara PAH dan PH-LHD (khususnya pada HFpEF). Dilema ini menekankan derajat variabilitas yang tinggi, dan perbedaan dapat dijelaskan melalui studi populasi pasien, dimana metode akhir ekspirasi ditemukan sesuai dalam membedakan PAH dan HF-pEF, sedangkan nilai rerata digital dapat lebih sesuai untuk digunakan pada pasien PPOK dimana sering sekali ditemukan respiratory swing.Penggunaan metode akhir ekspirasi pada pembacaan nilai PAWP menunjukkan hubungan korelasi yang baik dengan pengukuran langsung LVEDP, dan pada pola pre- kapiler [1,9]. Rekomendasi dari 5th World Symposium on Pulmonary Hypertension 2013 di Nice, mengatur standarisasi pengukuran PAWP untuk membedakan PAH dan PH-LHD :

- Zero level (titik nol) : titik nol patokan harus diatur pada posisi mid-thorakal, dimana mewakili lokasi atrium kiri. 
- Nilai ambang PAWP : nilai ambang untuk membedakan HP pre- dan post- kapiler adalah 15 mmHg, namun kecurigaan PH-HFpEF harus ditingkatkan pada nilai ambang antar 12-15 mmHg utamanya pada pasien dengan diuresis dan/atau faktor risiko LHD.

- Pembacaan nilai PAWP : PAWP harus dinilai pada kondisi akhir ekspirasi, dimana efek swing tekanan intratorakal paling minimal. Pasien tidak boleh menahan nafas, dan tidak boleh melakukan manuver Valsava.

- Pengukuran langsung LVEDP : perlu dipertimbangkan bia PAWP tidak dapat terukur, atau jika dicurigai adanya LHD yang signifikan $[1,9]$.

A

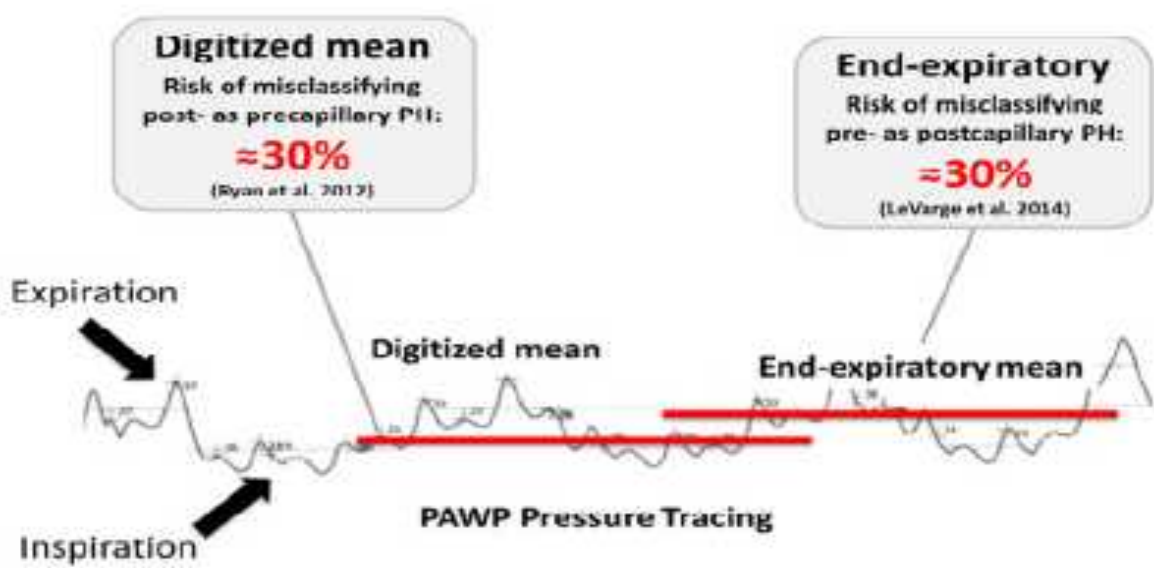

B

70 year-old patient

HFPEF, volume overload

Body weight $80 \mathrm{~kg}$
Same patient 6 days later

aftor volumo doplotion

Body weight $73 \mathrm{~kg}$
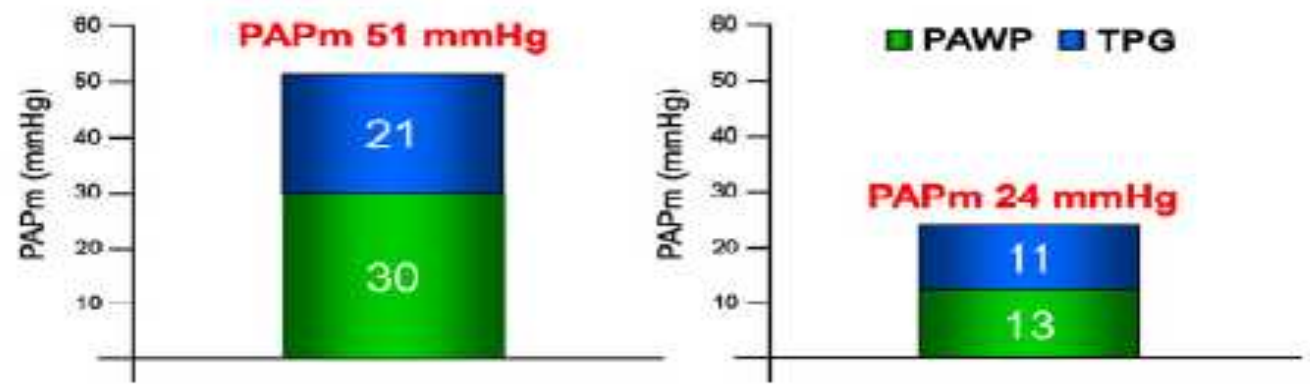

Gambar 5. Pulmonary artery wedge pressure (PAWP). (A) Potensi misklasifikasi antara HP predan post- kapiler bergantung pada metode pembacaan PAWP, (B) Contoh pasien dengan HPHFpEF sebelum (kiri) dan sesudah (kanan) pemberian diuretik, menunjukkan dampak beban volume pada hemodinamik paru [1]

\section{PERBEDAAN HIPERTENSI ARTERI PULMONAL DAN HIPERTENSI PULMONAL AKIBAT PENYAKIT JANTUNG KIRI}

Guideline terbaru mengindikasikan bahwa RHC wajib dilakukan untuk mengkonfirmasi diagnosis HP, dan - berdasarkan PAWP - untuk memungkinkan klasifikasi hemodinamik sebagai HP pre- atau post- kapiler.Gambar 6 menunjukkan suatu algoritme diagnosis untuk membantu mengintegrasikan RHC dan temuan non-invasif, dan menentukan penyebab yang mendasari dan patofisiologi HP dalam konteks LHD. Pasien yang dicurigai memiliki HP perlu menjalani evaluasi 
klinis dan pemeriksaan dasar non-invasif, dan jika terdapat indikasi perlu dilakukan pemeriksaan tambahan. Penggunaan anamnesis, EKG, dan ekokardiografi secara simultan dapat membantu membedakan PAH dari PH-LHD. Manifestasi klinis, temuan spesifik dan hasil pemeriksaan yang mengarahkan pada diagnosis PAH dan/atau PH-LHD dapat dilihat di Tabel 1 [1].

Tabel 1. Hasil uji diagnostik non-invasif dapat menunjukkan diagnosis PAH atau PH-LHD ${ }^{1}$

\begin{tabular}{|c|c|c|}
\hline & Suggustive of PAH (Nicu group 1) & Suggestive of PH.LHD (Nice groy 2) \\
\hline $\begin{array}{l}\text { ONeal } \\
\text { features }\end{array}$ & 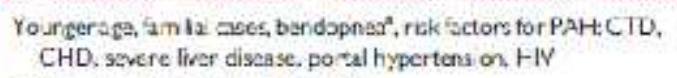 & $\begin{array}{l}\text { Older sce, hypertension, dabetes, CaL, BMI > } 30 \text { putmionary } \\
\text { congestion hibtery of pumoniary osdema. orthopnosa }\end{array}$ \\
\hline hrts. & AV hyre trophy, right asis, RV ctrain & 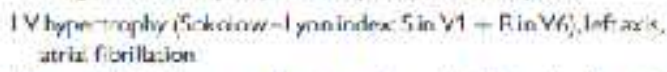 \\
\hline$-E C H C^{n}$ & 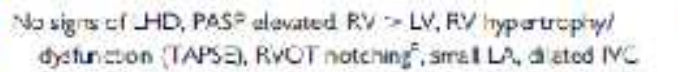 & 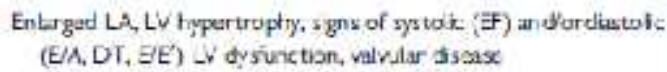 \\
\hline $\begin{array}{l}1 \text { Qhes: } \\
\text { Xary: }\end{array}$ & Enlarged rght heart thembars, $d$ hated $\mathrm{PQ}_{4}$, penpheral PA p un ng & $\begin{array}{l}\text { Pulmorary coneaton, Kerby E Ines, peural etusiens } \\
\text { eniarganen: o' lef. heart chambers }\end{array}$ \\
\hline - prinaro & 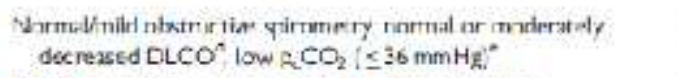 & 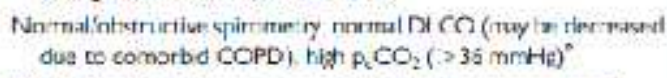 \\
\hline Sacmarkass & 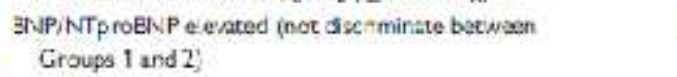 & $\begin{array}{l}\text { BN=NNTproB SP slevated inot dikcriminase between group } 1 \\
\text { and 2) }\end{array}$ \\
\hline$\varnothing$ GFET & 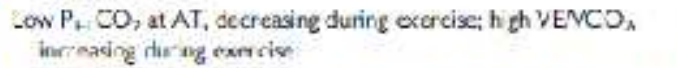 & 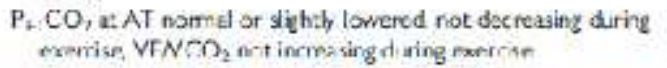 \\
\hline LAR-CT & $\begin{array}{l}\text { To diagncse cr rule out parenchmal lung disease (not discriminate } \\
\text { benween Groups } 1 \text { and } 2 \text { ) }\end{array}$ & $\begin{array}{l}\text { To diagnose or rule out parenchymal une disase (not discrininate } \\
\text { between. Groupe } 1 \text { and } 2 \text { ) }\end{array}$ \\
\hline$\forall$ Wa:an & 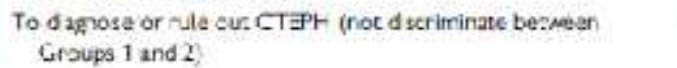 & $\begin{array}{l}\text { To diagnose er rue out CTEPH inot discrim rate between } \\
\text { Groups } 1 \text { and } 2 \text { ) }\end{array}$ \\
\hline
\end{tabular}

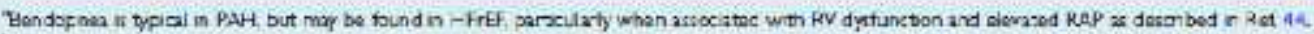

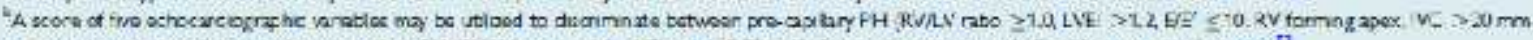

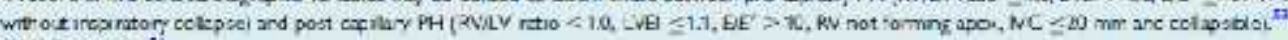
RVur notehng?

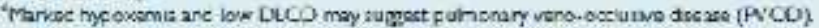

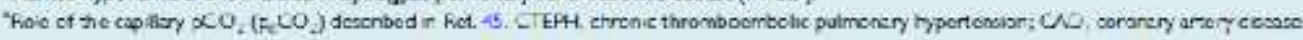

Oleh karena kita hanya berfokus pada perbedaan PAH dan PH-LHD, tidak dibicarakan mengenai bentuk HP lainnya (Nice Groups 3-5). Pada kasus HP yang ringan dengan LHD yang dominan, pemeriksaan lanjutan untuk HP biasanya tidak diperlukan. Sebaliknya, kateterisasi jantung kiri dapat merupakan indikasi, dan LHD diobati. Jika dicurigai adanya PAH, atau ditemukan adanya HP berat sebagai tambahan pada LHD yang ringan, maka penilaian invasif hemodinamik paru dengan kateterisasi jantung kiri (right heart catheterization / RHC) merupakan indikasi [3].

Saat melakukan RHC, ada 3 hal utama yang harus dilakukan (3 C) (Gambar 6) :

1. Confirm : keberadaan HP harus dikonfirmasi dengan nilai PAP rata-rata $\geq 25 \mathrm{mmHg}$.

2. Complete : penting untuk mendapatkan keseluruhan set pemeriksaan hemodinamik paru, seperti pengukuran PAP (sistolik, diastolik, dan rata-rata), RAP, curah jantung, indeks jantung, mixed venous oxygen saturation, penghitungan TPG, DPG, PVR. Selanjutnya, hemodinamik paru selalu diinterpretasikan dalam hubungannya dengan resistensi vaskuler sistemik (PVR/SVR ratios).

3. Characterize : HP perlu dikarakteristikan sebagai pre-, isolated post- capillary, atau combined preand post- capillary, dengan bergantung pada penilaian tekanan pengisian ventrikel kiri, baik diukur sebagai PAWP ataupun LVEDP [1]. 


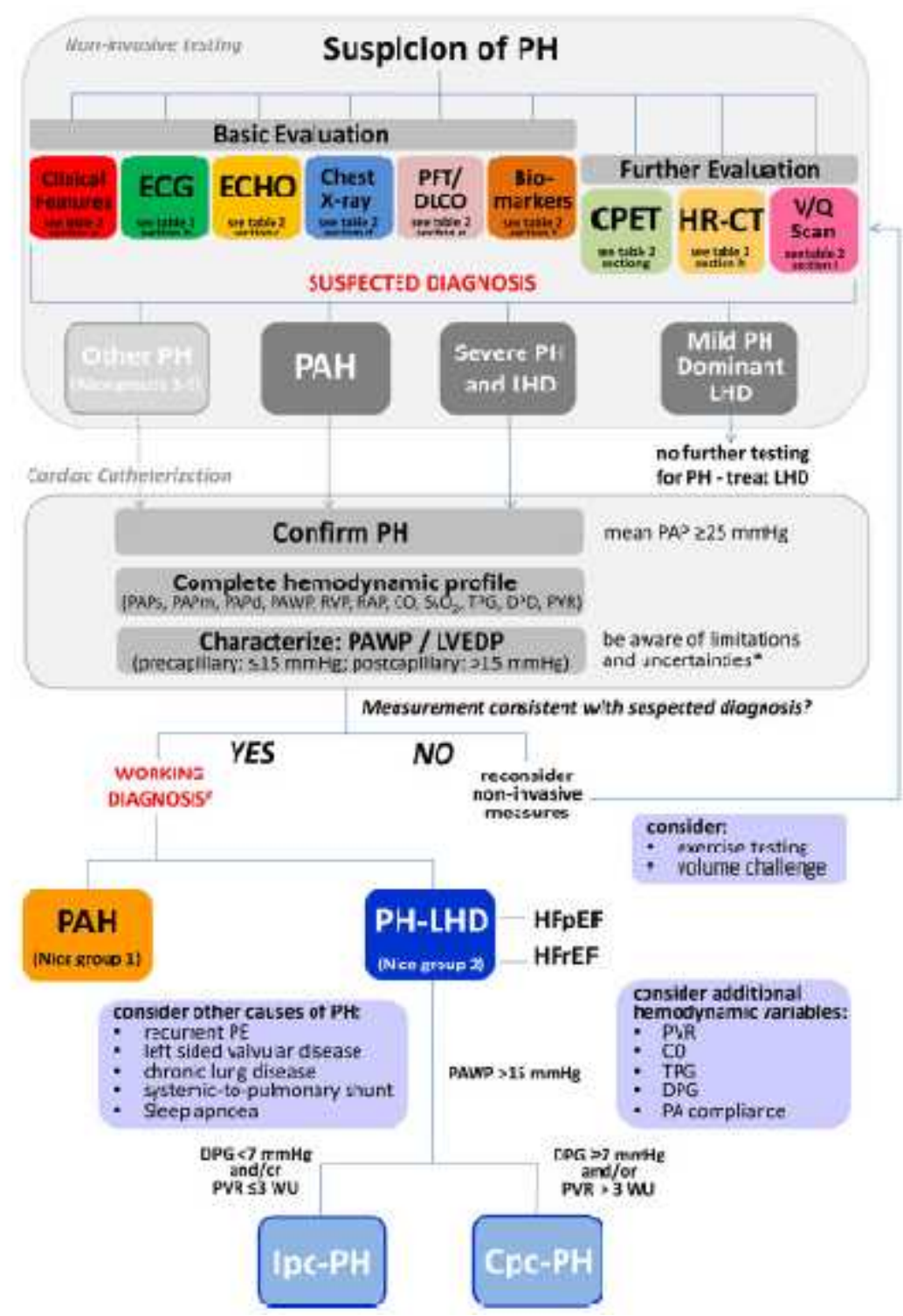

Gambar 6. Diagnosis banding antara PAH (Nice Group 1) dan PH-LHD (Nice Group 2). Tampak adanya suatu algoritme diagnosis, menggabungkan uji non-invasif, dan variabel hemodinamik yang dinilai dengan kateterisasi jantung. Ipc- $\mathrm{PH}=$ isolated post-capillary $\mathrm{PH}, \mathrm{Cpc}-\mathrm{PH}=$ combined post- and pre- capillary PH [1]

\section{ALAT NON-INVASIF UNTUK MEMBEDAKAN HIPERTENSI ARTERI PULMONAL DAN HIPERTENSI PULMONAL PADA GAGAL JANTUNG DENGAN FRAKSI EJEKSI BAIK}

Saatdisfungsi sistolik pada pasien PH-HfrEF biasanya lebih mudah terdeteksi, menemukan perbedaan pasti antara PAH dan PH-HFpEF lebih sulit untuk dilakukan. Tanpa memperhatikan ada tidaknya HP, ada alat-alat non-invasif yang dapat digunakan untuk menentukan keberadaan disfungsi diastolik ventrikel kiri. Standar baku emas untuk menilai fungsi diastolik ventrikel kiri adalah dengan menggunakan estimasi volume ventrikel kiri dengan metode konduktansi invasif. Sebagai alternatif modalitas non-invasif, ekokardiografi yang komprehensif (yang dikombinasikan dengan peptida natriuresis) dapat digunakan untuk mendiagnosis HF-pEF berdasarkan pernyataan konsensus. Penilaian ekokardiografi untuk HF-pEF meliputi estimasi LVEDP dengan mengukur E/E', penilaian ukuran atrium kiri, rasio E/A, dan waktu deselerasi. Penjumlahan skor integratif dari 5 variabel ekokardiografi (rasio RV/LV, left ventricular eccentricity index/LVEI, RV forming apex, width and 
inspiratory collapse of $I V C$ ), dan juga parameter tambahan seperti bentuk $R V$ outflow tract Doppler envelope (RVOT notching) dapat digunakan untuk membedakan HP pre- dan post- kapiler $[1,10]$.

\section{PENATALAKSANAAN HIPERTENSI PULMONAL PADA GAGAL JANTUNG KIRI}

Dampak prognostik HP dan disfungsi ventrikel kanan pada gagal jantung kiri menyediakan rasionalisasi untuk mentargetkan HP sebagai pilihan terapi tambahan yang potensial baik pada HFrEF maupun HF-pEF. Meskipun demikian, sangat penting untuk menentukan penyebab dan keparahan HP, sebelum keputusan untuk menerapi dibuat. Oleh karena itu, suatu pemeriksaan diagnostik yang komprehensif sangat dibutuhkan, dan terapi terhadap gagal jantung (baik farmakologis maupun intervensi) menjadi satu-satunya terapi yang dapat diberikan. Namun, pilihan terapi pada HF-pEF masih sangat terbatas, dan klasifikasi HP dapat berbeda pada masing - masing individu [11,13].

\section{PENATALAKSANAAN PENYAKIT JANTUNG KIRI DAN PENURUNAN TEKANAN PENGISIAN VENTRIKEL KIRI}

Dampak klinis peningkatan PAWP/LVEDP dan PAP pada pasien gagal jantung kiri memerlukan perhatian khusus. Terapi yang optimal terhadap penyakit jantung kiri yang mendasari meliputi terapi medis (mencapai target dosis) dan terapi intervensi (yakni CRT, ICD, LVAD, MitraClip) seringkali membantu menurunkan tekanan pengisian jantung kiri dan selalu merupakan tujuan/target primer pada pengobatan pasien gagal jantung. Namun, pertimbangan hemodinamik paru dapat membantu, dan deplesi volume biasanya berkaitan dengan penurunan substansial tekanan pengisian ventrikel kiri (PAWP/LVEDP), PAP, dan TPG. Pada konteks ini, uji trial CHAMPION menunjukkan bahwa pertimbangan penggunaan PAP sebagai target terapi tambahan secara signifikan menurunkan laju hospitalisasi akibat gagal jantung, baik pada HF-rEF maupun HF-pEF $[1,4]$.

\section{PERBAIKAN REGURGITASI MITRAL PADA GAGAL JANTUNG}

Pada pasien HF-rEF dengan dilatasi ruang jantung kiri, regurgitasi mitral fungsional adalah hal yang lumrah, dan dapat menjadi penyebab utama hipertensi pulmonal, dan berakibat peningkatan mortalitas. Bahkan HP dan disfungsi ventrikel kanan yang diinduksi oleh aktivitas saat ini menunjukkan keterkaitan dengan outcome yang jelek pada pasien dengan regurgitasi mitral asimptomatik. Terapi perbaikan katub mitral menggunakan pendekatan berbasis kateterisasi seperti Mitral Clipping atau Cardio-Band menunjukkan perbaikan yang signifikan pada hemodinamik paru, termasuk reduksi PAP dan PAWP rata-rata (utamanya via reduksi pada v-wave) dan peningkatan curah jantung/indeks kardiak. Perbaikan katub mitral perkutaneus mampu memperbaiki gejala klinis, kapasitas latihan, kualitas hidup, dan angka hospitalisasi akibat gagal jantung. Oleh karena dapat berakibat HP pada pasien dengan gagal jantung kiri, maka perbaikan setiap kondisi regurgitasi mitral harus segera dimulai pada pasien yang telah mendapatkan terapi medis yang optimal $[1,3]$.

\section{Terapi Target pada Hipertensi Pulmonal pada Pasien dengan Gagal Jantung Kiri}

Berdasarkan dampak prognostik HP dan disfungsi ventrikel kanan pada HF-rEF dan HF-pEF, maka terapi HP sebagai tambahan pada terapi gagal jantung tampaknya cukup menjanjikan. Terapi target yang disetujui untuk terapi dari PAH meliputi endothelin receptor antagonist (ERA), prostanoid, phosphodiesterase-5 inhibitor (PDE5i), dan stimulator of soluble guanylate cyclase (sGC). Perlu ditekankan bahwa tidak ada satupun dari terapi tersebut merupakan komponen yang disetujui untuk terapi PH-LHD. Suatu kekhawatiran penggunaan obat dengan target untuk PAH ada pasien dengan LHD adalah terjadinya vasodilatasi pulmonal dan peningkatan aliran darah pulmonal akibat peningkatan tekanan pengisian jantung kiri sehingga berpotensi menyebabkan edema paru dan dekompensatio kordis $[1,3]$. 
Beberapa studi randomized controlled trial (RCT) mempelajari efikasi dan keamanan penggunaan ERA dan prostanoid pada pasien PH-LHD, dan menunjukkan hasil yang tidak menguntungkan atau bahkan terbukti merugikan. Sebagai contoh, pada uji trial FIRST, yang mempelajari efek epoprostenol intravena pada pasien $\mathrm{PH}-\mathrm{HFrEF}$, harus segera dihentikan oleh karena munculnya tren peningkatan mortalitas pada kelompok yang diterapi dibandingkan dengan kelompok yang diberi plasebo. Data mengenai penggunaan ERA pada pasien PH-HFpEF masih sangat minim, dan berhubungan dengan peningkatan edema perifer. Suatu studi terbaru berfokus pada jalur NO pada pasien dengan PH-LHD (Tabel 2). Suatu studi RCT "RELAX" menunjukkan bahwa PDE5i sildenafil tidak memperbaiki konsumsi oksigen puncak dan kapasitas latihan pada pasien dengan HFpEF tanpa HP $[3,4]$.

Suatu metanalisis dari 6 studi RCT yang mempelajari efikasi dan keamanan PDE5i pada pasien dengan HFrEF menunjukkan bahwa penambahan PDE5i dalam regimen terapi mampu memperbaiki hemodinamik dam kapasitas latihan, serta menurunkan gejala klinis dan angka hospitalisasi dibandingkan dengan plasebo. Suatu cara alternatif untuk memodulasi jalur NO adalah dengan stimulasi sGC. Suatu stimulator sGC, riociguat (yang telah disetujui untuk PAH dan CTEPH yang inoperabel), telah dipelajari pada 2 RCT pada pasien PH-LHD. Pada pasien dengan PH-HFrEF, uji trial LEPHT gagal untuk mencapai target menurunkan PAP dibandingkan plasebo, namun menunjukkan peningkatan pada indeks kardiak dan penurunan PVR. Sedangkan pada pasien dengan PH-HFpEF, uji trial DILATE menunjukkan hasil yang serupa. Hal ini menunjukkan efek sistemik dan/atau kardiak dari riociguat dibandingkan dengan efek vasodilatasi pulmonal [1,6,7].

Tabel 2. Ringkasan uji trial yang sedang diteliti maupun yang telah rampung mengenai PH-LHD ${ }^{1}$

\begin{tabular}{|c|c|c|c|c|c|c|}
\hline Drux & $n$ & Sart & E.d & Duraio: & P inary andpoin: & Secmindary andpuints \\
\hline \multicolumn{7}{|l|}{ If wht ratuosd Ef } \\
\hline $\begin{array}{l}\text { Rocingat } \\
\text { itint }\end{array}$ & $\Delta \mathrm{Al}$ & \multicolumn{2}{|c|}{ Rauts wointis: } & is weted & Giente in mPNof far bexelire & 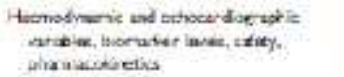 \\
\hline 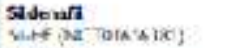 & $2 *$ & $x: 012$ & $52 \times+$ & $24 w \Rightarrow$ & 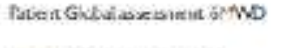 & 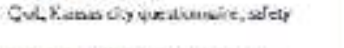 \\
\hline 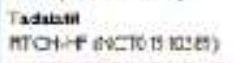 & 1100 & \multicolumn{2}{|c|}{ 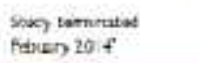 } & Lp to be montent & 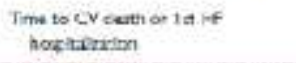 & 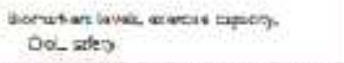 \\
\hline \multicolumn{7}{|l|}{ if mili peexind Is } \\
\hline $\begin{array}{l}\text { grdeart } \\
\text { nELax }\end{array}$ & 216 & \multicolumn{2}{|c|}{ Reallowide } & 24 wash. & 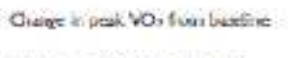 & 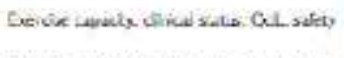 \\
\hline $\begin{array}{l}\text { Sedenart } \\
\text { Hedeis } \leq \alpha^{*}\end{array}$ & $\therefore$ & \multicolumn{2}{|c|}{ fuevert quabia } & 12 wnes: & Olange in míA torr bacirn & 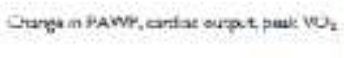 \\
\hline $\begin{array}{l}\text { Recinesat } \\
\text { Tali AIT? }\end{array}$ & 4 & \multicolumn{2}{|c|}{ Resuls wevile: } & 15 wat. & 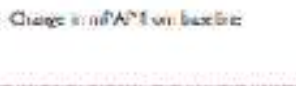 & 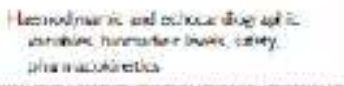 \\
\hline \multicolumn{7}{|l|}{ if midht $\Rightarrow 3$ ss } \\
\hline 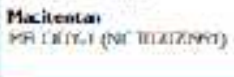 & $\omega$ & $5 \times 1+$ & torest. & 12 wask. & 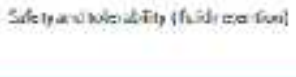 & 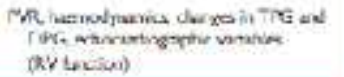 \\
\hline
\end{tabular}

\section{KESIMPULAN}

Pada pasien dengan gagal jantung kiri, hipertensi pulmonal sering ditemukan dan merupakan komplikasi yang mengancam jiwa, namun sayangnya masih sering diabaikan dalam praktek klinis sehari-hari. Peningkatan prevalensi dan insidens gagal jantung, khususnya HF-pEF, dan prognosis yang buruk pada pasien yang menunjukkan tanda hipertensi pulmonal dan disfungsi ventrikel kanan akibat gagal jantung kiri, membutuhkan suatu pengertian lebih lanjut mengenai patofisiologi PH-LHD dan untuk menentukan suatu pendekatan berbasis bukti pada manajemen pasien dengan gagal jantung yang mengalami hipertensi pulmonal. Adanya terminologi baru dari PH-LHD (Ipc-PH vs. Cpc-PH) telah meningkatkan peran penilaian klinis dan membantu mencegah penggunaan obat-obatan PAH yang tidak tepat pada kondisi PH-LHD. 


\section{DAFTAR PUSTAKA}

[1] Rosenkranz S, Gibbs JSR, Wachter R, de Marco T, Vonk-Noordegraaf A, Vachiery JL. Left ventricular heart failure and pulmonary hypertension. Eur Heart J 2016;37(12):942-54.

[2] Galie` N, Hoeper MM, Humbert M, Torbicki A, Vachiery JL, Barbera JA, Beghetti M,Corris P, Gaine S, Gibbs JS, Gomez-Sanchez MA, Jondeau G, KlepetkoW, Opitz C,Peacock A, Rubin L, Zellweger M, Simonneau G; ESC Committee for PracticeGuidelines (CPG). Guidelines for the diagnosis and treatment of pulmonary hypertension:The Task Force for the Diagnosis and Treatment of Pulmonary Hypertensionof the European Society of Cardiology (ESC) and the European RespiratorySociety (ERS), endorsed by the International Society of Heart and Lung Transplantation(ISHLT). Eur Heart J 2009; 30: 2493-2537.

[3] Miller WL, Grill DE, Borlaug BA. Clinical features, hemodynamics, and outcomes of pulmonary hypertension due to chronic heart failure with reduced ejection fraction. JACC Heart Fail 2013; 1: 290-299.

[4] Gerges C, Gerges M, Lang MB, Zhang Y, Jakowitsch J, Probst P, Maurer G, Lang IM. Diastolic pulmonary vascular pressure gradient. A predictor of prognosis in out-ofproportio pulmonary hypertension. Chest 2013; 143: 758-766.

[5] Vachiery JL, Adir Y, Barbera JA, Champion H, Coghlan JG, Cottin V, De Marco T, Galie` N, Ghio S, Gibbs JS, Martinez F, Semigran M, Simonneau G, Wells A, Seeger W. Pulmonary hypertension due to left heart diseases. J Am Coll Cardiol 2013; 62(Suppl D): D100-D108.

[6] Tampakakis E, Leary PJ, Selby VN, De Marco T, Cappola TP, Felker GM, Russell SD, Kasper EK, Tedford RJ. The diagnostic pulmonary gradient does not predict survival in patients with pulmonary hypertension due to left heart disease. JACC Heart Fail 2015; 3: 9-16.

[7] Dragu R, Rispler S, Habib M, Sholy H, Hammerman H, Galie N, Aroson D. Pulmonary arterial capacitance in patients with with heart failure and reactive pulmonary hypertension. Eur J Heart Fail 2015; 17: 74-80.

[8] Mohammed SF, Hussain I, Abou Ezzeddine OF, Takahama H, Kwon SH, Forfia P, Roger VL, Redfield MM. Right ventricular function in heart failure with preserved ejection fraction: a community-based study. Circulation 2014; 130: 2310-2320.

[9] Ryan JJ, Rich JD, Thiruvoipati T, Swamy R, Kim GH, Rich S. Current practice for determining pulmonary capillary wedge pressure predisposes to serious errors in the classification of patients with pulmonary hypertension. Am Heart J 2012; 163: 589-594.

[10] Paulus WJ, Tscho pe C, Sanderson JE, Rusconi C, Flachskampf FA, Rademakers FE, Marino P, Smiseth OA, De Keulenaer G, Leite-Moreira AF, Borbe' ly A, Edes I, Handoko ML, Heymans S, Pezzali N, Pieske B, Dickstein K, Fraser AG, Brutsaert DL. How to diagnose diastolic heart failure: a consensus statement on the diagnosis of heart failure with normal left ventricular ejection fraction by the Heart Failure and Echocardiography Associations of the European Society of Cardiology. Eur Heart J 2007; 28:2539-2550.

[11] Rosenkranz S, Bondermann D, Buerke M, Felgendreher R, ten Freyhaus H, Grünig E, de Haan F, Hammerstingl C, Harreuter A, Hohenforst-Schmidt W, Kindermann I, Kindermann M, Kleber FX, Kuckeland M, Ku"bler WM, Mertens D, Mitrovic V, Opitz C, Schmeisser A, Schulz U, Speich R, ZehW,Weil J. Pulmonary hypertension due to left heart disease: Updated recommendations of the Cologne Consensus Conference 2011. Int J Cardiol 2011; 154: S34S44. 